\title{
Characteristics and protection experience of historical buildings in Macao
}

\author{
Yuji Li \\ Department of history, JiNan University, Guangzhou, Guangdong Province, China \\ yukilee2005@126.com
}

Keywords: Macao; Historical building; Characteristic; Protection experience

\begin{abstract}
The historical buildings have been eroded in varying degrees by urban development and construction with the development of economic and commercial society, as a result of which, the overall style of the historic district has been destroyed. Historical building is the witness of human development trace, which reflects the regional culture to a certain extent. Therefore, the protection of historical buildings also means the protection of the regional culture. The Macao SAR government has accumulated a lot of experience in the protection of historical buildings. The historical building resources of Macao were sorted in this article, to analyze the cultural characteristics of historical buildings, and the experience of the Macao SAR government in protecting historical buildings was summarized, with the hope to bring some inspiration for the protection of domestic historical buildings.
\end{abstract}

\section{Introduction}

The Macao Peninsula was an important channel for the Maritime Silk Road in the sixteenth century and also the earliest missionary center in the Far East. The culture of Macao was rooted in the Chinese society, and in 1557, the Portuguese brought the Portuguese culture after they entered Macao. Then the missionaries carried out the activities of Western learning spreading to the East, and Macao acted as the intermediary role of Chinese and Western culture. In the history of urban development, the Eastern and Western cultures collided with each other, maintained their distinctive features, achieved coexistence and symbiosis, created a unique Macao culture, and formed the Chinese and Western combined and unique architectural style. Since 1953, the Macao SAR government has started to protect the cultural relic buildings and has accumulated a lot of valuable experience. Therefore, it is of certain reference significance for domestic cities to carry out the protection of historical buildings, by studying the characteristics of historical buildings in Macao, sorting its protection experience and analyzing the main problems.

\section{Historical building resources in Macao}

The historical building heritages of Macao refer to the historical buildings and building groups with historical value, technical value and architectural art value in Macao, which can reflect the unique architectural style and can be representative in the development history of the region.

At present, there are 128 historical buildings protected in Macao, which are divided into four categories. The first category is the commemorative building: 52 places, such as the Ruins of the Cathedral of Saint Paul, the A-Ma Temple, the Guia Fortress and the lighthouses. The second category is the building with architectural art value: 44 places, such as the Quartel dos Mouros, the Dom Pedro V Theatre, and the Army Club and so on. The third category is the protected building group: 11 places, such as the Largo do Lilau and the Long Tou Li, the Holland Garden Road and the 
Love Lane. And the fourth category is the protected area: 21 places, such as the Lujiu Garden, the Penha Hill and the October Fifth Street. ${ }^{[1]}$ In these historical buildings, 25 historical buildings (or places) such as the A-Ma Temple, the Mandarin's House, the Holy House of Mercy, the St. Lawrence Church and the Monte Fortress have formed the historical and cultural district of Macao, which was formally approved by the United Nations Educational,Scientific and Cultural Organization (UNESCO) to be included in the World Cultural Heritage List in 2005. Macao has become the famous world cultural heritage city, and is also the thirty-first city heritage of our country. These architectural cultural heritages are of great historical value, as the memory of the city, the concrete embodiment of the city style, and the important carrier to inherit the regional culture of Macao.

\section{Cultural characteristics of historical buildings in Macao}

The architectural development track of Macao in the past more than 400 years, took the Macao architectural culture characterized by the combination of Chinese and Western cultures, as the main line of architectural development in Macao. Before the Portuguese entered Macao to establish the permanent residence in 1557, Macao was only an island fishing village with the simple customs. In 1557, the Portuguese entered Macao and began to settle and trade, there were also immigrants from Spain, Britain, Italy, Japan and even Africa, and Macao became a real international city in China. The Portuguese dominated Europeans built churches, roads, fortresses and cemeteries in Macao, with their different ideas, cultures and customs, which created the urban landscapes and urban life that are quite different from traditional Chinese cities. During this period, the Portuguese also brought the western architectural forms and styles to Macao, such as western Classical style, Baroque style, Neoclassical style, Eclectic style, Romantic style, Portuguese Colonial style, Rome style, European style, Decorative style, and Islamic architectural style, etc., ${ }^{[2]}$ which produced new variants in Macao by fusing various other architectural elements in Asia, to form the unique architectural style of Macao.

To sum up, the historical buildings in Macao mainly have the following characteristics:

First, Chinese and western buildings retain their own characteristics in the overall style and reflect each other. The Chinese temples in Macao kept their traditional characteristics and were not influenced by western buildings. The government buildings were generally in the western style, and were not influenced by traditional Chinese buildings, which shows that the blending did not prevent the two styles from being pure in the innovating process. ${ }^{[3]}$ For example, there are the Dom Pedro $\mathrm{V}$ Theatre at the Gangding Square that Portuguese often went to, and the traditional old residence of the Chinese gentry, He Dong. There stands the small Na T cha Temple beside the lofty Ruins of the Cathedral of Saint Paul, and there is also the earliest Chinese market, Camp Street beside the solemn St.Dominic's Church in Macao.

Second, Chinese and western buildings co-exist and assimilate the advantages of each other. $^{[4]}$ The Portuguese and Macao residents interacted with each other in daily life, and the cultural exchanges were inevitably generated, which are reflected in the architectural style, with both the Oriental implication and western sentiment, such as the relief on the Ruins of the Cathedral of Saint Paul, with both the image of the western angel and the Chinese peony pattern meaning a good fortune. Although the Mandarin House is a typical Chinese-style house, there are western open balconies, and also the engraving of the fences and eaves in the western style. 


\section{Protection experience of historical buildings in Macao}

The protection of historical buildings in Macao is mainly carried out by the Department of Cultural Heritage under the Macao Cultural Affairs Bureau. The Department of Cultural Heritage is mainly responsible for clearing, restoring, repairing and reopening the chattel and real estate (including historical sites, buildings with architectural art value, and building groups and sites under protection), giving views on the protection of urban landscapes by restricting the construction plan within the protected area and formulating the related plan of repairing the damaged cultural relics.

\subsection{Protecting historical buildings through legislative means}

After rounds of consultation, the Macao SAR government promulgated the Law on the Protection of Cultural Heritages on March 1, 2014, which stipulates the protection and development of historical and cultural heritages from law, and emphasizes that the protection work is not independent but pluralistic, and it must be connected with urban construction, government function, fund guarantee, social supervision and public participation. The Protection Law enacted the protection policy of cultural heritages, reexamined the concept of cultural property, formulated a clear definition for various types of cultural heritages, listed the list of new material and intangible cultural heritages, and provided legal basis for the promotion of cultural heritage protection in an all-round way.

\subsection{Mobilizing multiple forces to activate historical buildings}

The historical buildings in Macao are protected by the government and not allowed to be demolished, with the main protection activities such as maintenance, reinforcement and innovation and utilization, but the original features and styles of the positive facades of the buildings are absolutely necessary to be maintained, both for Chinese buildings and western buildings. The activation mode of historical buildings in Macao is to repair private property with the fund paid by the government, the plan made by the folk association, and the management by the enterprise, so that it can continue by its own management.

The most successful activation example of historical buildings in Macao is the project of Decheng Pawnshop, which is regarded as a model of public-private-partnership (PPP). Decheng Pawnshop was originally a property of the rich merchant Gao Kening in Macao, and also a pawnshop building with a complete structure in Macao, which was listed as a historical building under protection in Macao. The pawn industry is an ancient traditional industry in Macao, and also a special industry, the existence and development of which are closely related to the poverty of the residents and the prevalence of gambling in the past. According to the historical records, pawnshops in Macao had appeared in the Qing Dynasty, and in the 30s and 40s of the last century, the pawn industry was developing rapidly in Macao. Because of the outbreak of the Anti-Japanese War, many people in Hong Kong and the mainland came to Macao to avoid the war. At that time, there was a shortage of supplies and price increasing of all things, and many people could only mortgage objects in the pawnshops to solve the urgent problems. Then the economy of Macao was rapidly developed in the 1970-1980, the people's living standard was also improved, the rise of the banking industry and the emergence of some new types of pawnshops had greatly influenced the old pawn industry, and many old pawnshops had been closed one after another. In 1993, Decheng Pawnshop was declared closed, and the traditional "pawnshop" disappeared in Macao, which had become a historical memory of the people. In March 2001, the Macao Cultural Affairs Bureau negotiated with the building owner, Galaxy Development Co., Ltd., so as to preserve the history and culture of 
Macao, and resumed the face of the past pawnshops. The owners agreed with the government's views, and maintained and protected the pawnshops and Kuta with the Macao Cultural Affairs Bureau. And the government provided funds for the protection works and offered preferential treatment to the owners of the two buildings in the property tax. The Macao Cultural Affairs Bureau is responsible for the maintenance of the building, and the whole pattern of the pawnshop was set up in accordance with the basic mode of the Chinese pawnshop in the early period of the Republic of China, regardless of its appearance, the internal display and the stationery of pawn records. The pawnshop history is displayed in it, and it was renamed the "Cultural Hall". The specific operation is undertaken by Galaxy Development Co., Ltd., to show the pawnshop development of Macao with the original appearance of pawnshop. The restoration project of Decheng Pawnshop was awarded the Honorable Mention of the "UNESCO Asia-Pacific Heritage Protection Award" in 2004.

\subsection{Setting up the reward and punishment system to protect the historical buildings}

The Macao SAR government has established the award for cultural heritage conservation and restoration, to commend the outstanding contributors to the conservation and restoration of historical buildings. If the historical buildings assessed as the cultural heritages or listed in the protected area are in good condition and have obtained the projects approved by the Cultural Affairs Bureau in advance, the owners of them may apply for exemption from the urban housing tax or the reduction by half of the tax on business or industry in the commercial or industrial sites in the historical buildings. ${ }^{[5]}$ In terms of the damage to historical buildings assessed as the cultural heritages, such as demolishing historical buildings, if the perpetrator is a natural person, the fine of 20-100 million yuan in Macao should be paid. And if the perpetrator is a legal person, the fine of 50-500 million yuan in Macao should be paid and the legal liability of the perpetrator shall be investigated.

\subsection{Propagating the protection concept of historical buildings in multichannels}

The Macao SAR government continuously publicizes the knowledge about historical and cultural heritages through television, newspaper and network and other medias, and constantly cultivates the interest of public participation. At the same time, the major decision-making in the protection and development process of historical buildings in Macao has also introduced the public consultation procedure, to ensure that residents can participate in the formulation and implementation of the historical building protection policy, which is conducive to enhancing the awareness level and consciousness of local residents on the protection of historical buildings in Macao.

However, because of the historical and practical reasons, there are also some problems in the protection and development of historical buildings in Macao, for example, the main investment body in the protection of historical buildings is the government, the investment of the private capital is insufficient, and the enterprises with intention to participate in the restoration and activation of buildings are mostly small and medium enterprises with the limited investment strength. Due to the lack of diversified investment and financing system, the long-term dependence on government subsidies tends to lead to the lack of potential of continuous development. In addition, there are insufficient local professionals in the protection of historical and cultural buildings in Macao, and the overall level of education is not high, which restricts the improvement of the protection and development level of historical buildings. 


\section{Conclusion}

The protection and development of historical buildings is essentially a matter of reconstruction of historical buildings in urban development. The historical buildings of Macao have an important value for the world cultural heritage, as a full reflection of the blend of Chinese and western cultures in the city style and historical architecture, and the remarkable feature of Macao that is different from the other cities in the world. The Macao SAR government attaches great importance to the historical buildings, and has set up special institutions to maintain and protect them. The rational and effective historical building protection is of great significance for maintaining the regional cultural characteristics of Macao, of which the protection experience and concept are worth learning in the domestic cities.

\section{References}

[1] The website of the Macao Cultural Affairs Bureau: http://www.culturalheritage.mo/gb/list/9/

[2] Tong Qiaohui,Spatial Characteristic of Traditional Street in Peninsula of Macau,Huazhong Architecture[J],2005(12),103-106.

[3] Ma Yue, Chen Weixin,The Evolution And Alienation Of Macao's Architectural Style,World Architecture[J],2009(12),130-133.

[4] Zhao Bingshi,Riview and Prospect:Urban Development ans Architecture Features in Macao,World Architecture[J],1999(12),16-20.

[5] Chen Yu, The Developing Process of Contemporary Architecture in Macao,World Architecture[J],1999(12),21-26. 